\title{
Behavior of Japanese quail in different air velocities and air temperatures
}

\author{
Tatiany Carvalho dos Santos ${ }^{(1)}$, Richard Stephen Gates ${ }^{(2)}$, Ilda de Fátima Ferreira Tinôco(1), \\ Sérgio Zolnier ${ }^{(1)}$ and Fernando da Costa Baêta ${ }^{(1)}$
}

\begin{abstract}
(1)Universidade Federal de Viçosa, Departamento de Engenharia Agrícola, Avenida Peter Henry Rolfs, s/no, CEP 36570-900 Viçosa, MG, Brazil. E-mail: taty17_carvalho@hotmail.com, iftinoco@hotmail.com, zolnier@ufv.br, baetafc@gmail.com (2)University of Illinois, Department of Agricultural and Biological Engineering, Urbana-Champaign, 1304, West Pennsylvania Avenue, Urbana IL 61801 USA. E-mail: rsgates@illinois.edu
\end{abstract}

\begin{abstract}
The objective of this work was to evaluate the combined effects of air temperature and air velocity on the behavior of Japanese quail (Coturnix coturnix japonica). A total of 216 Japanese quail in their initial laying phase were used. Bird behavior was categorized with an ethogram (eat, drink, stop, open wings/shiver, others). The experimental design was a randomized complete block, in a $4 \times 4$ factorial arrangement, with four air velocities $\left(0,1,2\right.$, and $\left.3 \mathrm{~m} \mathrm{~s}^{-1}\right)$ and air temperatures $\left(17,23,29\right.$, and $\left.35^{\circ} \mathrm{C}\right)$. The behavior "stop" was greater when the birds were subjected to $17^{\circ} \mathrm{C}$. At $35^{\circ} \mathrm{C}$, a significant reduction $(\mathrm{p}<0.05)$ was observed in the behavior "eat" at $0 \mathrm{~m} \mathrm{~s}^{-1}$, compared with the other velocities. The behaviors of laying quail are similar in the morning and in the afternoon. Quail remain stopped for a longer time under cold stress conditions, at $17^{\circ} \mathrm{C}$.
\end{abstract}

Index terms: Coturnix coturnix japonica, cold stress, ethology, heat stress, thermal sensation.

\section{Comportamento de codornas japonesas em diferentes velocidades e temperaturas do ar}

\begin{abstract}
Resumo - O objetivo deste trabalho foi avaliar o efeito combinado da temperatura e da velocidade do ar no comportamento de codornas japonesas (Coturnix coturnix japonica). Utilizaram-se 216 codornas japonesas na fase inicial de postura. Os comportamentos das aves foram estabelecidos no etograma comportamental (comer, beber, parar, abrir asas/arrepiar, outros). Utilizou-se o delineamento experimental de blocos ao acaso, em arranjo fatorial $4 \mathrm{x} 4$, com quatro velocidades do ar $\left(0,1,2\right.$, e $\left.3 \mathrm{~m} \mathrm{~s}^{-1}\right)$ e temperaturas do ar $(17,23,29$ e $35^{\circ} \mathrm{C}$ ). O comportamento "parar" foi maior quando as aves foram submetidas a $17^{\circ} \mathrm{C}$. À temperatura de $35^{\circ} \mathrm{C}$, houve redução significativa $(\mathrm{p}<0,05)$ para o comportamento "comer" a $0 \mathrm{~m} \mathrm{~s}^{-1}$, em comparação às demais velocidades. Os comportamentos das codornas poedeiras são semelhantes no período da manhã e da tarde. As codornas permanecem mais tempo paradas em condições de estresse por frio, a $17^{\circ} \mathrm{C}$.
\end{abstract}

Termos para indexação: Coturnix coturnix japonica, estresse por frio, etologia, estresse por calor, sensação térmica.

\section{Introduction}

Japanese quail (Coturnix coturnix japonica) breeding has gained prominence and attracted the attention of breeders, as quail show rapid growth, early sexual maturity, high productivity, low feed consumption, and long production period (Castro, 2014).

Thermal comfort of quail breeding is of fundamental importance, especially for laying quails, for a long period of time, since low or high temperatures may compromise their behavior, as well as performance and egg production (Vercese et al., 2012), and high air velocities can further exacerbate, or relieve, these conditions through the effect of convective cooling/ heating and creating a different effective temperature. Thermal stress can be defined as the interaction between protective reactions and stress factors (Renaudeau et al., 2012). Thus, in order to obtain the best performance of a given production system, it is necessary that it operates within the zone of thermal comfort for the animals (Ribeiro et al., 2016).

The thermal environment affects the behavior of laying birds and, through the expression of these factors, it is possible to better understand its effects on birds, allowing inferences about animal welfare (Pereira et al., 2015). High environmental temperatures may have a negative effect on the welfare 
and performance of laying birds (El-Tarabany, 2016), such as behavioral changes, for example, reduced food consumption and tendency to remain prostrated, with wings open, as an attempt to dissipate body heat to the environment (Santos et al., 2012). Effects of air velocity may alleviate heat stress in moderate to hot conditions, but can exacerbate cold stress by excess convective cooling.

Quail have good egg production when the minimum and maximum temperatures do not exceed 5 and $30^{\circ} \mathrm{C}$, respectively (Albino \& Barreto, 2012). According to Sousa et al. (2013), the air temperature range which best characterizes the thermal comfort zone for adult quail is around $23^{\circ} \mathrm{C}$ and may extend up to $26^{\circ} \mathrm{C}$; and according to El-Tarabany (2016), the thermal comfort for laying quail is around $23.8^{\circ} \mathrm{C}$.

The use of techniques that facilitate the dissipation of the internal heat of the facilities is necessary to provide comfort and well-being to laying quails in industrial farms. Fans play an important role in the aviary environment. Air velocity is one of the major environmental factors involved in thermal regulation, especially when birds are exposed to high environmental temperature, which may directly affect their behavior. High air velocity values, such as $3 \mathrm{~m} \mathrm{~s}^{-1}$, can improve egg production, while low levels such as $0.5 \mathrm{~m} \mathrm{~s}^{-1}$ may adversely affect production (Ruzal et al., 2011). According to Ferreira (2016), air velocity within aviaries may range from 0.2 to $3 \mathrm{~m} \mathrm{~s}^{-1}$ for adult birds, with the environmental air temperature between 15 and $28^{\circ} \mathrm{C}$, and the relative air humidity varying from 40 to $80 \%$. The popularity of tunnel ventilation for poultry systems worldwide is evidence of the importance of air velocity in helping to control heat stress. However a lack of information is available for laying quail.

In this sense, since there is a need to better understand the behavioral responses of quail to the environment, especially in the laying phase, new studies related to the environment are necessary.

The objective of this work was to evaluate the combined effects of air temperature and air velocity on the behavior of Japanese quail.

\section{Materials and Methods}

All procedures of the experimental phase were approved by the ethics committee on animal use (Protocol no. 72/2015), of Universidade Federal de
Viçosa (CEUA/UFV), in the state of Minas Gerais, Brazil.

The study was carried out during March 2016, with four environment chambers located in the experimental area of the Núcleo de Pesquisa em Ambiência e Engenharia de Sistemas Agroindustriais (AmbiAgro), of the sector of rural constructions and ambience, belonging to the department of agricultural engineering of Universidade Federal de Viçosa. The climate of the region, according to Köppen-Geiger climate classification, is characterized by cold and dry winters, and hot and humid summers.

Each climate chamber was $3.2 \mathrm{~m}$ long, $2.44 \mathrm{~m}$ wide, and $2.38 \mathrm{~m}$ high, and was equipped with an electric resistance air heater $(2,000 \mathrm{~W})$, a Split type hot/cold air conditioner $(3,500 \mathrm{~W})$. Both of these were operated by a MT-531R plus electronic microcontroller (Full Gauge Controls, Canoas, RS, Brazil), with control temperature of -10 to $70^{\circ} \mathrm{C}$, resolution of $0.1^{\circ} \mathrm{C}$, relative humidity of 20 to $85 \%$, and resolution of $0.1 \% \mathrm{RH}$, which was installed in each climatic chamber to control the air temperature and relative humidity. An air humidifier with a water volume of $4.5 \mathrm{~L}$ and a humidification potential of $300 \mathrm{~mL}$ per hour was automatically used as needed. Ventilation in each chamber was provided by two FD08025S1M AMB axial fans, using DC 12V and 0.15A (Ambition Technology Company, Guangdong, China), with automatic activation, allowing air renewal every 15 minutes (four air changes per hour).

The research was conducted in the initial phase of Japanese quail egg laying, from 60 days of age, i.e., eight weeks. The birds were placed in four climatic chambers and randomly distributed in eight galvanized wire cages (two per chamber, measuring $1 \times 0.42 \times 0.42 \mathrm{~m})$. Birds were initially maintained in acclimatization at a thermoneutral temperature of $23^{\circ} \mathrm{C}$ (Sousa et al., 2013; El-Tarabany, 2016) until at least $50 \%$ of birds had production of eggs.

Each cage had three partitions, with 27 birds per cage. In order to meet the breeding density used in field, an area of approximately $155.6 \mathrm{~cm}^{2}$ per bird was used (Sousa et al., 2013). The artificial conditioning of the climatic chambers was performed by 12 axial fans with plastic propeller and diameter of $23 \mathrm{~cm}$, associated with a $50 \mathrm{~W}$ Elgin micromotor, with exhaust fan or blower air flow, and volumetric flow rate of $950 \mathrm{~m}^{3} \mathrm{~h}^{-1}$. A ventilation control system was used, with two fans 
coupled in a PVC tube, one at each end, with an opening along the tube, and air outflow directed towards the birds. Each treatment combination was evaluated for a period of three days, which was suggested by the Ethics Committee, since the birds were subjected to stress by cold and heat.

In general, the maximum air velocity that is applied to broilers is $2.5 \mathrm{~m} \mathrm{~s}^{-1}-3.0 \mathrm{~m} \mathrm{~s}^{-1}$. Based on this and on studies with other birds, air velocity values were set to be evaluated for the quail: $0,1,2$, and $3 \mathrm{~m} \mathrm{~s}^{-1}$, with a fixed value for each climatic chamber. The ventilation system was operated from 5:30 a.m. to 9:30 p.m., when it was turned off (16 hours per day of ventilation) only in climatic chambers with velocities of 1,2 , and $3 \mathrm{~m} \mathrm{~s}^{-1}$.

The comfort temperature for quail was assumed to be $23^{\circ} \mathrm{C}$ (Sousa et al., 2013; El-Tarabany, 2016). Four temperature levels were established: moderate cold $\left(17^{\circ} \mathrm{C}\right)$, thermal comfort $\left(23^{\circ} \mathrm{C}\right)$, moderate heat $\left(29^{\circ} \mathrm{C}\right)$ and severe heat $\left(35^{\circ} \mathrm{C}\right)$, so that there was a difference of $6^{\circ} \mathrm{C}$ between each evaluated condition, simulating possible cold and heat discomfort to observe behavioral changes in birds. Two days of acclimatization were established in the change from one temperature to another, and the comfort temperature recommended in the literature was used. The relative air humidity (RH) was kept close to $70 \%$, ranging between 40 and $80 \%$, as indicated by Ferreira (2016). Four MT-531R plus electronic microcontrollers (Full Gauge Controls, Canoas, RS, Brazil) were used with: control temperature of -10 to $70^{\circ} \mathrm{C}$, resolution of $0.1^{\circ} \mathrm{C}$; relative humidity of 20 to $85 \%$, resolution of $0.1 \%$ UR. One was installed in each climatic chamber to control temperature and air relative humidity.

To control the thermal environment, at 10 minute measurement intervals, each chamber's values of air temperature (AT), relative humidity $(\mathrm{RH})$, and dew point temperature $\left(t_{d p}\right)$ were continuously recorded by four temperature and relative humidity sensors of Hobo-LCD Temperature/Relative Humidity model (Onset Computer Corporation, Bourne, MA, USA), which store the temperature in a measuring range between $-20^{\circ} \mathrm{C}$ and $+50^{\circ} \mathrm{C}$, relative humidity between 0 and $100 \%$, and with respective accuracies of $\pm 0.20^{\circ} \mathrm{C}$ and $\pm 2.5 \%$. The black globe temperature (BGT) was obtained by means of four mini temperature recording sensors, model 174 (Testo, Campinas, SP, Brazil), with resolution of $0.1^{\circ} \mathrm{C}$, measuring range between $-30^{\circ} \mathrm{C}$ and $70^{\circ} \mathrm{C}$, and accuracy of $\pm 0.5^{\circ} \mathrm{C}$. This instrument was placed in the center of a black globe, with $15 \mathrm{~cm}$ in diameter and $0.5 \mathrm{~mm}$ thick, painted externally with flat black ink. The sensors and the black globe were installed inside each climatic chamber at the height of the birds (1.10 $\mathrm{m}$ above the floor) outside of the cages to obtain representative values.

With the data of the climatic variables, the black globe humidity index (BGHI) was calculated, using the equation proposed by Buffington et al. (1981): $\mathrm{BGHI}=\mathrm{BGT}+0.36 \mathrm{TDP}+41.5$; in which $\mathrm{BGHI}$ is the black globe humidity index, dimensionless; BGT is the black globe temperature, in ${ }^{\circ} \mathrm{C}$; and TDP is the dew point temperature, also in ${ }^{\circ} \mathrm{C}$.

The behavioral evaluation method was of the instantaneous type (Catalan et al., 2013), that is, it was performed on stored video images from each partition of each cage according to the behavioral ethogram (Table 1), with duration of approximately $5 \mathrm{~s}$ of observation for each quail. Thus, the number of birds that were performing a certain category of behavior at that very time was recorded. Monitoring was performed daily, for two consecutive hours in the morning (9 a.m. to 11 a.m.) and two hours in the afternoon ( 3 p.m. to 5 p.m.), with observations every 30 minutes (Barbosa Filho et al., 2007). For behavioral evaluation, birds were monitored for three consecutive days for each proposed environmental condition and air velocity, thus providing fifteen observations each

Table 1. Categories and behavioral ethogram ${ }^{(1)}$ used for laying quail.

\begin{tabular}{|c|c|c|}
\hline$\overline{\text { Categories }}$ & Behavior & Description \\
\hline No. 1 & Eat & $\begin{array}{l}\text { Head directed into the feeder, } \\
\text { eating }\end{array}$ \\
\hline No. 2 & Drink & $\begin{array}{c}\text { Drinking at drinker/pecking } \\
\text { at drinker }\end{array}$ \\
\hline No. 3 & $\begin{array}{c}\text { Stop, rest, shrink, group, } \\
\text { egg laying }\end{array}$ & $\begin{array}{c}\text { No movement, bird standing } \\
\text { still, shrunk, grouped or } \\
\text { crowded birds, performing } \\
\text { egg laying }\end{array}$ \\
\hline No. 4 & Open wings, deviate, bristle & $\begin{array}{l}\text { Open and stretched wings, } \\
\text { poultries away from each } \\
\text { other, bristle }\end{array}$ \\
\hline No. 5 & $\begin{array}{c}\text { Others (investigate feathers, } \\
\text { jumping, be aggressive, } \\
\text { shaking) }\end{array}$ & $\begin{array}{c}\text { Birds investigating their } \\
\text { own feathers or other birds' } \\
\text { feathers with the beak, } \\
\text { aggressiveness, dominance, } \\
\text { agitation }\end{array}$ \\
\hline
\end{tabular}

${ }^{(1)}$ Catalan et al. (2013). 
for morning and afternoon sessions per treatment combination. Bird behavior was recorded using two video cameras per chamber (totaling eight video cameras), model CAM 6015i, infrared, CCD Sharp 1/4, $420 \mathrm{TVL}$, minimum resolution of 420 lines and lens with focal length of $3.6 \mathrm{~mm}$ (Venetian, São Bento do Sul, SC, Brazil), installed in the ceiling of the interior of each climatic chamber, by directing one camera to each cage. The images were stored on a digital DVR 3100-SH video recorder (VMI Sistemas de Segurança, Lagoa Santa, MG, Brazil), with resolution 4 CIF, HDMI output, and VGA $1920 \times 1080$ P, 16 channels.

The behaviors selected for analysis were adapted from Hansen (1994), Elston et al. (2000) and Barbosa Filho et al. (2007). The selection of these behaviors was made based on a preliminary study of some quail submitted to the conditions that would be studied. The behaviors were divided into five categories established by the behavioral ethogram (Table 1).

The feed and water supply to the birds was carried out ad libitum three times a day (at 7 a.m., 1 p.m. and 7 p.m.). The water and feed management was carried out at least 1 hour before the behavioral evaluation, to avoid interference in the behavior of the birds. Trough feeders were used, as well as automatic nipple waterers with cup, which were always kept supplied. The light program was established according to Molino et al. (2015) for laying quail, using 15 hours of light and 9 hours of dark, throughout the experimental period.

The treatment combinations were represented in a $4 \times 4$ factorial arrangement: four temperatures and four air velocities arranged in a randomized complete block design. The experimental unit was defined as the cage partition, with three replicates per cage and two cages in each climatic chamber, totaling six replicates.

The behavior data were analyzed by period of day to test for statistical difference between treatments. Comparisons of behaviors between different temperatures and between different air velocities were performed in the morning and in the afternoon, both for temperatures and velocities. For this, the Sigma Plot 12.0 statistical software (Systat Software, Inc., San Jose, CA, USA) was used in the one-way analysis of variance ("One-Way Anova"), with grouping of treatment averages, and, after that, the significant treatments were subjected to Tukey's test, at 5\% probability.

\section{Results and Discussion}

The average temperature and humidity inside the chambers were close to those proposed for each thermal environment (Table 2). Chamber air temperature standard deviations varied from 0.4 to $2.0^{\circ} \mathrm{C}$ in daytime and from 0.5 to $1.1^{\circ} \mathrm{C}$ at night time. Relative humidity ranged from 69 to $73 \%$, and $\mathrm{BGHI}$ increased with the increase in temperature, from 65 to 86 (Table 2). $\mathrm{BGHI}$ had critical values at $17^{\circ} \mathrm{C}$ and from $29^{\circ} \mathrm{C}$; this could compromise quail performance by affecting their behavior. When working with Japanese laying quail subjected to different temperatures $(20,28,30$, and $32^{\circ} \mathrm{C}$ ), Castro (2014) obtained values of BGHI (71, 77,80 , and 82 , respectively) close to the ones found in the present study. According to Sousa et al. (2014), the BGHI around 75 is ideal for quail at this stage of breeding.

In general, significant differences in laying quail behavior were observed between all temperatures for the different air velocity levels during the morning (Figure 1 A, B, C, and D). At all air velocities, the behaviors "stop" and "other" were the most common, and the behavior "stop" was more frequent in the moderate cold treatment $\left(17^{\circ} \mathrm{C}\right)$, differing significantly from the other temperatures.

This last result was due to the moderate cold stress condition to which the birds were submitted, since the temperature in question was outside of the thermal comfort zone for laying quail, and directly influenced their behavior, leading to a greater number of birds in the "stop" category. Castro (2014), when working with Japanese laying quail subjected to

Table 2. Mean and standard deviation of air temperature (AT), relative humidity (RH), and black globe humidity index (BGHI) in each treatment, for laying quail, kept in cages inside climatic chambers, with 15 hours of photophase.

\begin{tabular}{lcccc}
\hline Treatments & \multicolumn{4}{c}{ Thermal environment } \\
\cline { 2 - 5 } & Period (h) & AT $\left({ }^{\circ} \mathrm{C}\right)$ & RH $(\%)$ & BGHI \\
\hline $17^{\circ} \mathrm{C}$, & 7 a.m. -7 p.m. & $17.8 \pm 1.3$ & $72.6 \pm 7.2$ & $64.8 \pm 1.7$ \\
moderate cold & 7 p.m. -7 a.m. & $23.3 \pm 0.7$ & $71.8 \pm 4.6$ & $72.2 \pm 0.9$ \\
\hline $23^{\circ} \mathrm{C}$, & 7 a.m. -7 p.m. & $23.4 \pm 0.4$ & $70.7 \pm 4.1$ & $72.1 \pm 0.7$ \\
thermal comfort & 7 p.m. -7 a.m. & $23.7 \pm 0.5$ & $72.2 \pm 3.8$ & $72.8 \pm 0.8$ \\
\hline $29^{\circ} \mathrm{C}$, & 7 a.m. -7 p.m. & $29.1 \pm 1.3$ & $70.7 \pm 4.7$ & $79.3 \pm 1.6$ \\
moderate heat & 7 p.m. -7 a.m. & $23.7 \pm 0.8$ & $70.2 \pm 9.4$ & $72.3 \pm 1.2$ \\
\hline $35^{\circ} \mathrm{C}$, & 7 a.m. -7 p.m. & $35.1 \pm 2.0$ & $69.4 \pm 5.0$ & $86.0 \pm 2,4$ \\
severe heat & 7 p.m. -7 a.m. & $23.7 \pm 1.1$ & $69.4 \pm 5.0$ & $72.2 \pm 1.4$ \\
\hline
\end{tabular}

Pesq. agropec. bras., Brasília, v.52, n.5, p.344-354, maio 2017 DOI: 10.1590/S0100-204X2017000500008 
temperatures of $20,22,24$, and $26^{\circ} \mathrm{C}$, observed signs of cold discomfort at $20^{\circ} \mathrm{C}$. Birds in discomfort caused by cold show physiological changes, such as maintaining minimal blood circulation to avoid losing heat to the environment, and thus remain still as a thermoregulatory defense mechanism (Nascimento et al., 2011; Pereira et al., 2015).

The behavior "eat" did not differ statistically between moderate cold and thermal comfort at any air velocity either in the morning or afternoon (Figures 1 and 2). However, at low temperatures, it would be expected that birds would increase food intake in order to increase metabolic heat production, as well as vasoconstriction, respiratory rate reduction, and water consumption reduction, leading the birds to group more often than other animals (Schiassi et al., 2015).

A greater number of birds expressed the "drinking" behavior with increase in temperature, both in the morning and in the afternoon, and a significant difference was observed between the temperature of $17^{\circ} \mathrm{C}$ and the other ones at $1 \%$ probability (Figures 1 and 2). This behavior was a reflection of the stress caused by high temperature, because, as temperature increased, the demand of the birds for water was
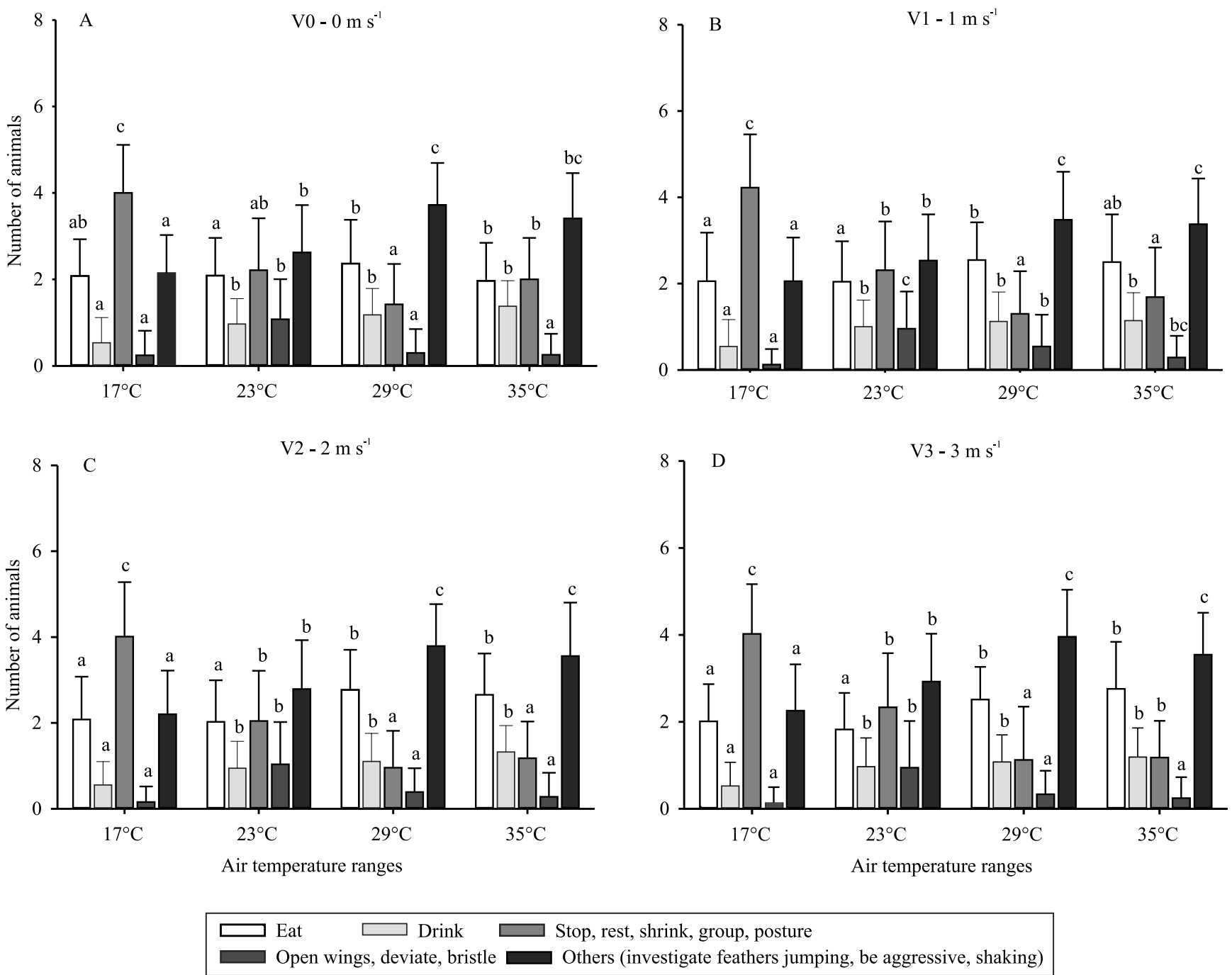

Figure 1. Mean values and standard deviation of the number of laying quail that expressed their behavior when subjected to four different temperature ranges and four different air velocities (A, B, C, and D) in the morning (9 a.m.-11 a.m.). The poultries were kept in cages, inside climatic chambers, with photophase of 15 hours. Equal letters in the columns indicate that there was no significant difference by Tukey's test, at $5 \%$ probability. 
greater. Khalil et al. (2006) also found that water consumption by laying quail increased at $35^{\circ} \mathrm{C}$. According to Barbosa Filho et al. (2007), under heat stress, the main behavior of birds is increased drinking frequency. Lara \& Rostagno (2013) noted that birds are sensitive to variations in environmental temperature, especially when subjected to heat stress. At high temperatures, birds resort to heat control mechanisms, such as decreased feed intake, increased water intake, and tendency to become more dispersed (Cordeiro et al., 2011).
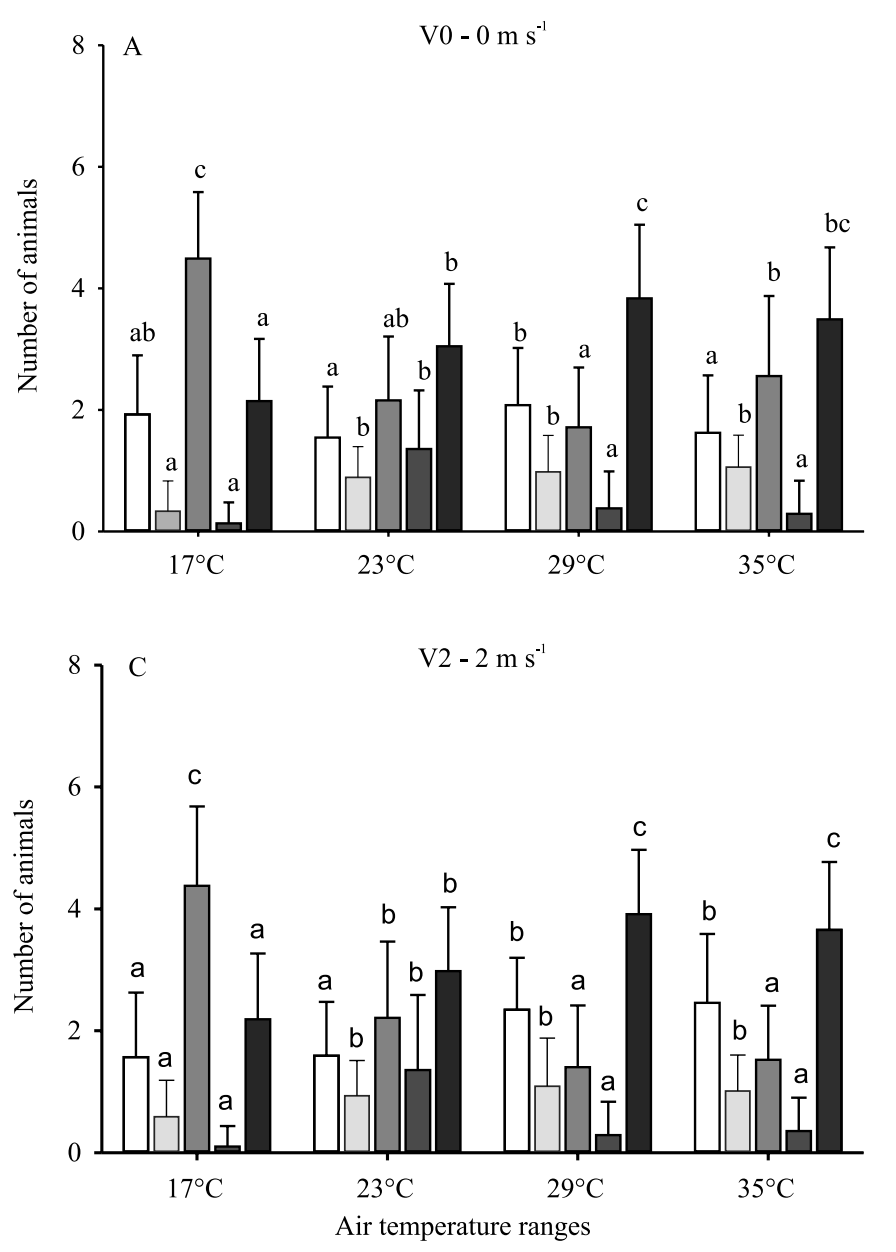

Significant differences amongst treatment combinations were observed for "open wings" behavior, with higher number of birds expressing this behavior at $23^{\circ} \mathrm{C}$, at all levels of air velocity, during mornings and afternoons (Figures 1 and 2). From the results, it can be inferred that this behavior, "open wings", refers to the state of thermal comfort in which the birds show active behaviors. However, Medeiros et al. (2005) noticed that when the birds were kept in warm environments with temperatures ranging from 32 to $36^{\circ} \mathrm{C}$, the birds became agitated, began to open
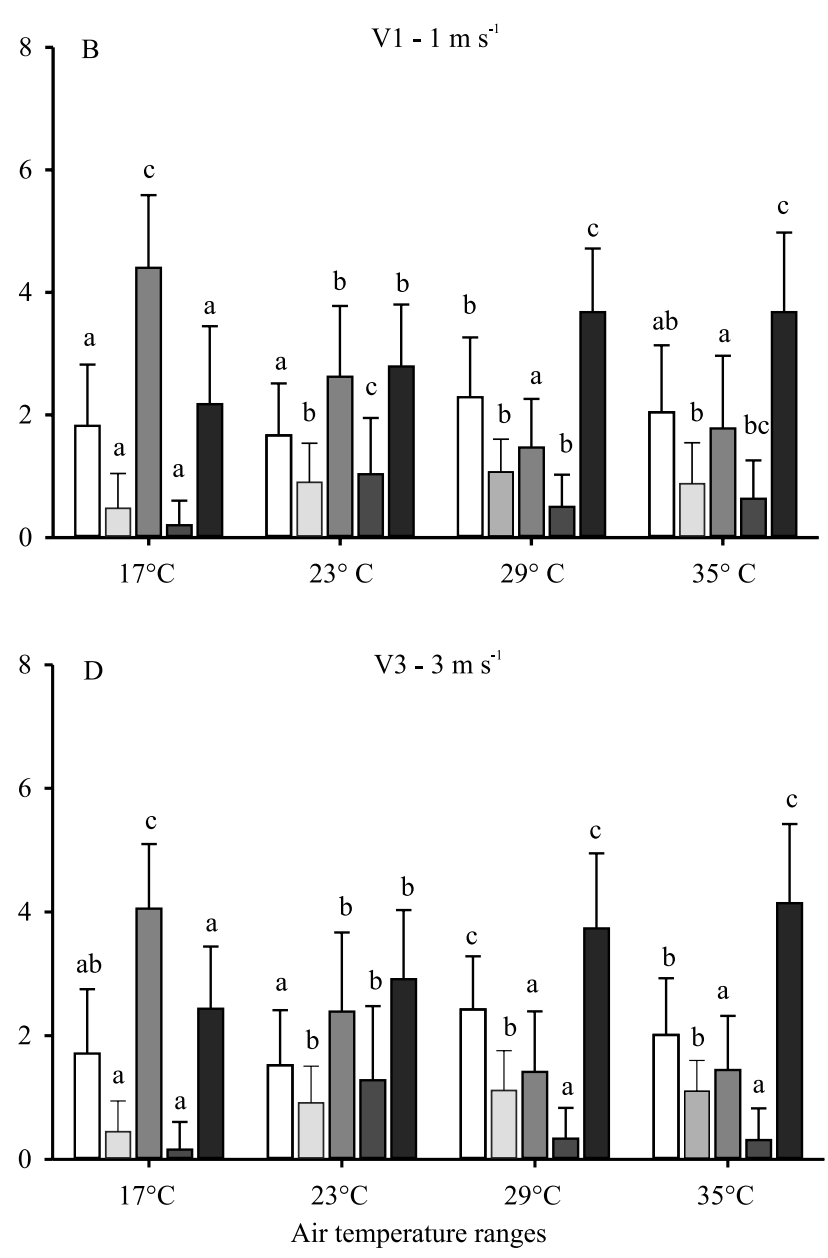

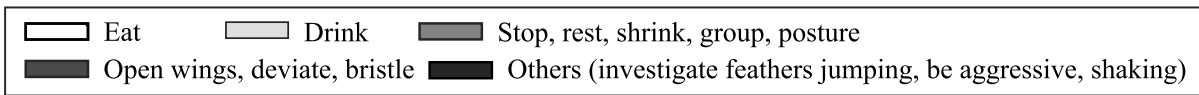

Figure 2. Mean values and standard deviation of the number of laying quail that expressed their behavior when subjected to four different temperature ranges and four air velocities (A, B, C, and D) in the afternoon ( 3 p.m. -5 p.m.). The birds were kept in cages, inside climatic chambers, with photophase of 15 hours. Equal letters in the columns indicate that there was no significant difference by Tukey's test, at 5\% probability. 
their wings more widely and got dispersed to increase the dissipation of body heat to the environment. Behavior to adjust thermoregulation is one of quail's most important responses to thermal stress (Khalil et al., 2012).

For the behavior "others", which includes studying feathers, jumping, aggressiveness, dominance, and agitation, there were more birds that expressed such behavior at 29 and $35^{\circ} \mathrm{C}$ at all levels of air velocity in the morning and in the afternoon, with no statistical differences (Figures 1 and 2). This category of behavior is most expressed at high temperatures, because it is a behavioral response to the stress suffered. These animals are involved in social conflicts, generating struggles for dominance of space or groups, and these conflicts lead to the production of heat by additional physical exercise, which occurred in these situations (Ferreira, 2016). According to Carvalho et al. (2013), when subjected to the thermal stress situations, birds tend to show atypical behavior, seeking to minimize the effects of the environment on their comfort.

In general, it was observed that most of the behaviors in the afternoon (Figure 2) were similar to those shown in the morning (Figure 1). In relation to the "eat" behavior, a significant difference was observed both in the morning and in the afternoon for the $0 \mathrm{~m} \mathrm{~s}^{-1}$ treatment at $35^{\circ} \mathrm{C}$ at $1 \%$ probability.

Differently from what was observed in the present study, Barbosa Filho et al. (2007) reported that the timetable of evaluation influences the expression of bird behavior, since all the animals follow a biorhythm due to the biological behavior, which is mainly related to the aspect of the photoperiod. Rodrigues et al. (2007) evaluated the behavior of laying quails under conditions of thermal comfort and heat stress, and observed that the birds spent more time investigating the feathers in the afternoon, when they were subjected to comfortable conditions; and that under the comfortable conditions, they remained longer in the "stop" behavior than under stress conditions. Khalil et al. (2012) observed that quail had less physical activity, with a tendency to stay longer in the "stop" behavior when kept in hot environments $\left(35^{\circ} \mathrm{C}\right)$.

However, in the present study, it can be observed that the "stop" behavior was more frequent when the birds were submitted to the low temperature $\left(17^{\circ} \mathrm{C}\right)$. Also for this behavior, no significant difference was found between temperatures 29 and $35^{\circ} \mathrm{C}$.
In environmental conditions of $17^{\circ} \mathrm{C}$ (moderate cold) and $23^{\circ} \mathrm{C}$ (thermal comfort), air velocity levels did not influence bird behavior (Figure $3 \mathrm{~A}$ and $\mathrm{B}$ ). This result can be justified by the fact that the birds were submitted to comfort temperature during the night, allowing recovery from the stress suffered.

For the environmental condition of $29^{\circ} \mathrm{C}$, there was a significant difference between the air velocities for the "stop" and "others" behaviors, with values of $p=0.002$ and $p=0.020$, respectively (Figure $3 \mathrm{C}$ ). For the "stop" behavior, the control treatment of $0 \mathrm{~m} \mathrm{~s}^{-1}$ differed only from that with air velocity of $3 \mathrm{~m} \mathrm{~s}^{-1}$, with a higher number of birds expressing this behavior in the $0 \mathrm{~m} \mathrm{~s}^{-1}$ treatment $(\mathrm{p}=0.002)$. For the "others" behavior, a significant difference was observed only between treatments 1 and $3 \mathrm{~m} \mathrm{~s}^{-1}$, being the same as the others $(\mathrm{p}=0.020)$.

When birds were subjected to severe heat stress $\left(35^{\circ} \mathrm{C}\right)$, it was possible to observe a significant difference for the "eat" behavior between the $0 \mathrm{~m} \mathrm{~s}^{-1}$ control treatment and those with air velocities of 1,2 , and $3 \mathrm{~m} \mathrm{~s}^{-1}$, with this behavior reduced to $0 \mathrm{~m} \mathrm{~s}^{-1}(\mathrm{p}<0.001)$. This fact was demonstrated by Medeiros et al. (2005), who reported that in environments considered hot (BGHI 78-88), as the air temperature rose from 26 to $36^{\circ} \mathrm{C}$, the relative humidity from $34 \%$ to $76 \%$, and the air velocity was reduced from 2.4 to $0.6 \mathrm{~m} \mathrm{~s}^{-1}$, the environment became increasingly unpleasant for birds due to thermal stress. There were no significant differences for "eat" and "others" behaviors between velocity levels at different air temperatures (Figure 4).

The behavior of the birds changed in the different evaluation periods, but did not statistically differ between air velocities in the morning, at 17 and $23^{\circ} \mathrm{C}$ (Figure $3 \mathrm{~A}$ and B). In the afternoon, the behaviors "drink" $(p=0.027)$ and "stop" $(p=0.030)$ were significant at $17^{\circ} \mathrm{C}$, and "stop" at $23^{\circ} \mathrm{C}(\mathrm{p}=0.034)$ (Figure $4 \mathrm{~A}$ and $\mathrm{B}$ ). There was a significant difference between the air velocities 0 and $3 \mathrm{~m} \mathrm{~s}^{-1}$ for the "stop" behavior at $17^{\circ} \mathrm{C}$, being the most expressive behavior in relation to the number of birds $(p=0.030)$ (Figure 4 A).

Also in the same environmental condition, a significant difference was observed between 0 and $2 \mathrm{~m} \mathrm{~s}^{-1}$ for the "drink" behavior $(\mathrm{p}=0.027)$ (Figure $4 \mathrm{~A}$ ). This indicates that the higher air velocity did not cause more birds to stand still or drink more water, which 
is an opposite result than expected, that is, bristle feathers (Figure 4 A).

However, Furtado et al. (2011), when evaluating bioclimatic and production indexes in laying hens, found values of air velocity above $6 \mathrm{~m} \mathrm{~s}^{-1}$, which created a condition of thermal discomfort for the birds, and influenced their productive performance. The air velocity range of 1.5 to $3.0 \mathrm{~m} \mathrm{~s}^{-1}$ was ideal to obtain good poultry zootechnical performance under hot conditions (Al-Dawood \& Büscher, 2014).

Under thermal comfort conditions, there was a significant difference $(p=0.034)$ between the 0 and
$1 \mathrm{~m} \mathrm{~s}^{-1}$ air velocities only for the "stop" behavior (Figure 4 B). Still at thermal comfort temperature, air velocity did not interfere with bird behavior.

There were no significant differences between morning air velocity levels for "drink" behavior at all temperature ranges and in the afternoon at temperatures 23,29 , and $35^{\circ} \mathrm{C}$ (Figure $4 \mathrm{~B}, \mathrm{C}$, and $\mathrm{D}$ ). However, Ruzal et al. (2011) observed that, in high temperatures and with a high rate of ventilation, there was higher water consumption. The presence of only one drinker available to the birds may have affected the results.
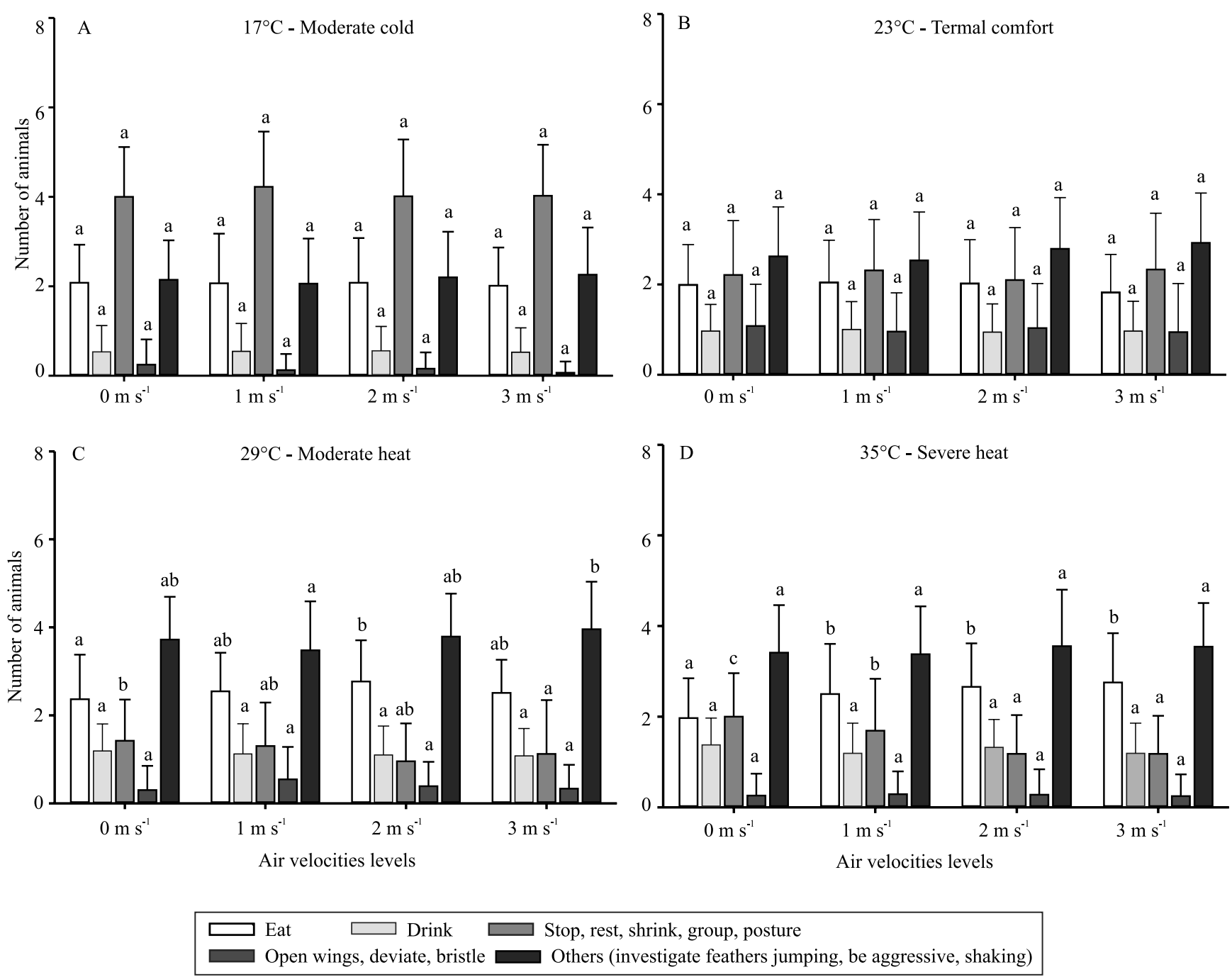

Figure 3. Mean values and standard deviation of the number of laying quail that expressed their behaviors, when submitted to four different air velocities, for four different temperature ranges (A, B, C, and D), in the morning (9 a.m. -11 a.m.). The birds were kept in cages, inside climatic chambers, with photophase of 15 hours. Equal letters in the columns indicate that there was no significant difference by Tukey's test, at $5 \%$ probability. 

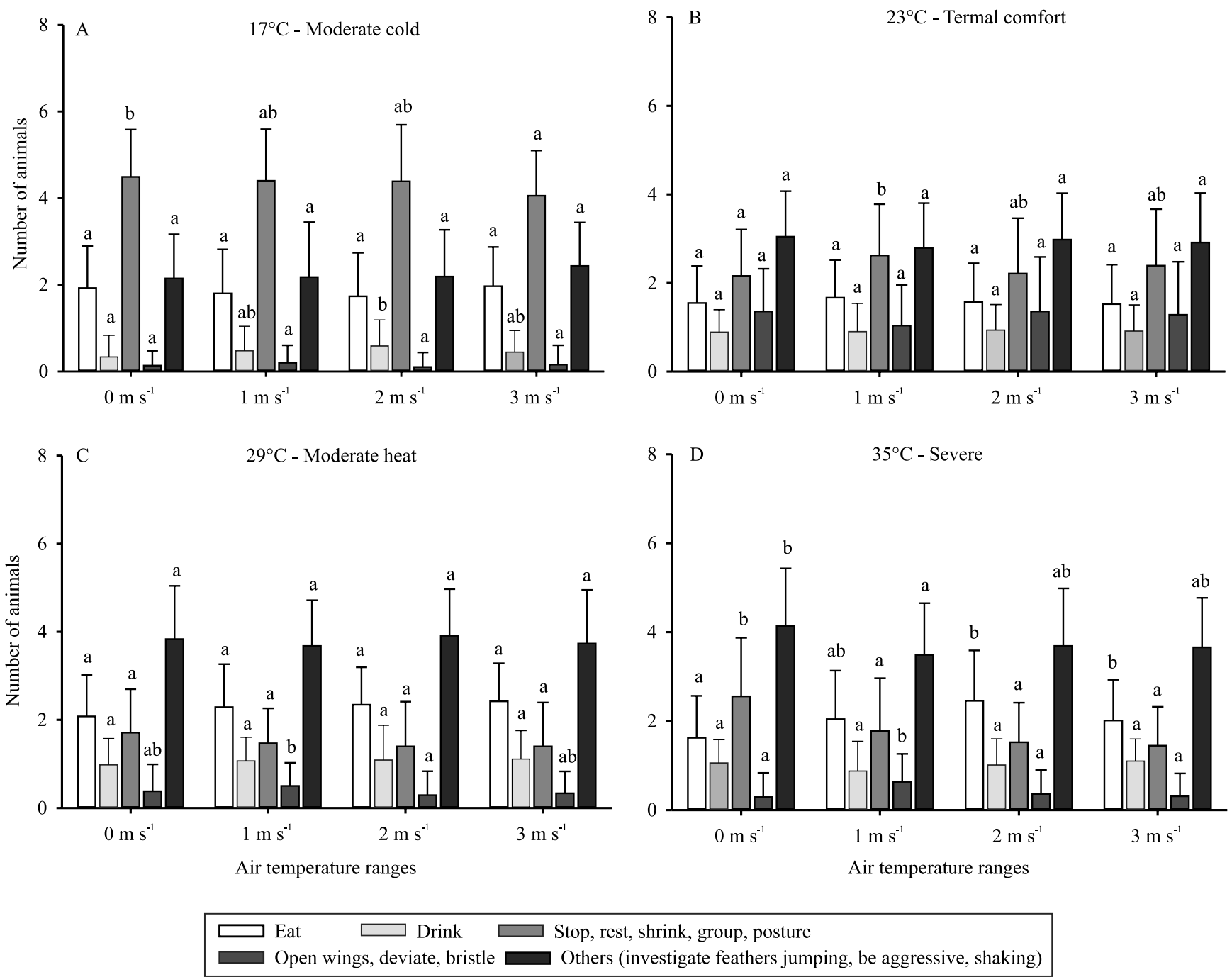

Figure 4. Mean values and standard deviation of the number of laying quail that expressed their behaviors, when submitted to four different air velocities, for four different temperature ranges (A, B, C, and D), in the afternoon ( 3 p.m. -5 p.m.). The birds were kept in cages, inside climatic chambers, with photophase of 15 hours. Equal letters in the columns indicate that there was no significant difference by Tukey's test, at $5 \%$ probability.

\section{Conclusions}

1. The behaviors of laying quail, subjected to four different temperatures $\left(17,23,29\right.$, and $\left.35^{\circ} \mathrm{C}\right)$ and air velocities $\left(0,1,2\right.$, and $\left.3 \mathrm{~m} \mathrm{~s}^{-1}\right)$ do not differ between the morning and afternoon periods.

2. The behavioral patterns "stop" and "others" (jumping, investigating feathers, aggressiveness, and agitation) were more prevalent for laying quail subjected to different air velocities and temperatures, especially for the behavior "stop" at $17^{\circ} \mathrm{C}$.
3. The behaviors "eat", "drink", and "others" tend to be greater as temperatures increase from 17 to $35^{\circ} \mathrm{C}$, regardless of air velocity.

4. The "eat" behavior, at $0 \mathrm{~m} \mathrm{~s}^{-1}$ and $35^{\circ} \mathrm{C}$, is observed in a smaller number of laying quail in the morning and afternoon.

\section{Acknowledgments}

To Núcleo de Pesquisa em Ambiência e Engenharia de Sistemas Agroindustriais (Ambiagro) 
of Universidade Federal de Viçosa (UFV), to Coordenação de Aperfeiçoamento de Pessoal de Nível Superior (Capes), and to Conselho Nacional de Desenvolvimento Científico e Tecnológico (CNPq), for financial support.

\section{References}

ALBINO, L.F.T.; BARRETO, S.L. de T. Criação de codornas para produção de ovos e carne. Viçosa: Aprenda Fácil, 2012. $268 \mathrm{p}$.

AL-DAWOOD, A.; BÜSCHER, W. Air velocity produced by different types of mixing and ceiling fans to reduce heat stress in poultry houses. International Journal of Agriculture and Forestry, v.4, p.145-153, 2014. DOI: 10.5923/j.ijaf.20140403.01.

BARBOSA FILHO, J.A.D.; SILVA, I.J.O.; SILVA, M.A.N.; SILVA, C.J.M. Avaliação dos comportamentos de aves poedeiras utilizando seqüência de imagens. Engenharia Agrícola, v.27, p.93-99, 2007. DOI: 10.1590/S0100-69162007000100002.

BUFFINGTON, D.E.; COLLAZO-AROCHO, A.; CANTON, G.H.; PITT, D.; THATCHER, W.W.; COLLIER, R.J. Black globe humidity index (BGHI) as comfort equation for dairy cows. Transactions of the ASAE, v.24, p.711-714, 1981. DOI: 10.13031/2013.34325.

CARVALHO, G.B. de; LOPES, J.B.; SANTOS, N.P. da S.; REIS, N.B. do N.; CARVALHO, W.F. de; SILVA, S.F.; CARVALHO, D.A de; SILVA, E.M. da; SILVA, S.M. da. Comportamento de frangos de corte criados em condições de estresse térmico alimentados com dietas contendo diferentes níveis de selênio. Revista Brasileira de Saúde e Produção Animal, v.14, p.785797, 2013. DOI: 10.1590/S1519-99402013000400012.

CASTRO, J. de O. Avaliação e modelagem do desempenho de codornas japonesas em postura submetidas a diferentes ambientes térmicos. 2014. 72p. Tese (Doutorado) - Universidade Federal de Lavras, Lavras.

CATALAN, A.A.S.; AVILA, V.S.; LOPES, L.L.; MONTAGNER, P.; VARGAS, G.D.; XAVIER, E.G.; ROLL, V.F.B. Perfil metabólico, hematológico e comportamental de poedeiras suplementadas com Panax ginseng. Archivos de Zootecnia, v.62, p.89-100, 2013. DOI: 10.4321/S0004-05922013000100010.

CORDEIRO, M.B.; TINÔCO, I.F.F.; MESQUITA FILHO, R.M. de; SOUSA, F.C. de. Análise de imagens digitais para a avaliação do comportamento de pintainhos de corte. Engenheria Agrícola, v.31, p.418-426, 2011. DOI: 10.1590/S0100-69162011000300002.

ELSTON, J.J.; BECK, M.M.; KACHMAN, S.D.; SCHEIDELER, S.E. Laying hen behaviour. 1. Effect of cage type and startle stimuli. Poultry Science, v.79, p.471-476, 2000. DOI: 10.1093/ ps/79.4.471.

EL-TARABANY, M.S. Impact of temperature-humidity index on egg-laying characteristics and related stress and immunity parameters of Japanese quails. International Journal of Biometeorology, v.60, p.957-964, 2016. DOI: 10.1007/s00484015-1088-5.
FERREIRA, R.A. Maior produção com melhor ambiente -para aves, suínos e bovinos. 3.ed. Viçosa: Aprenda Fácil, 2016. 401p.

FURTADO, D.A.; MOTA, J.K.M.; NASCIMENTO, J.W.B. do; SILVA, V.R. da; TOTA, L. da C.A. Produção de ovos de matrizes pesadas criadas sob estresse térmico. Revista Brasileira de Engenharia Agrícola e Ambiental, v.15, p.748-753, 2011. DOI: 10.1590/S1415-43662011000700014.

HANSEN, I. Behavioural expression of laying hens in aviaries and cages: frequencies, time budgets and facility utilisation. British Poultry Science, v.35, p.491-508, 1994. DOI: 10.1080/00071669408417715.

KHALIL, H.A.; GERKEN. M.; HASSANEIN, A.M.; MADY. M.E. Behavioural responses of two Japanese quail lines differing in body weight to heat stress. Egyptian Journal of Animal Production, v.42, p.151-158, 2012.

KHALIL, H.A.; HASSANEIN, A.M.; MADY, M.E.; GERKEN, M. Effect of housing conditions on performance of Japanese quail (Coturnix coturnix japonica) under cold stress in winter. Egyptian Journal of Animal Production, v.43, p.71-82, 2006.

LARA, L.J.; ROSTAGNO, M.H. Impact of heat stress on poultry production. Animals, v.3, p.356-369, 2013. DOI: 10.3390/ ani3020356.

MEDEIROS, C.M.; BAÊTA, F. da C.; OLIVEIRA, R.F.M. de; TINÔCO, I. de F.F.; ALBINO, L.F.T.; CECON, P.R. Efeitos da temperatura, umidade relativa e velocidade do ar em frangos de corte. Engenharia na Agricultura, v.13, p.277-286, 2005.

MOLINO, A.B.; GARCIA, E.A.; SANTOS, G.C.; VIEIRA FILHO, J.A.; BALDO, G.A.A.; ALMEIDA PAZ, I.C.L. Photostimulation of Japanese quail. Poultry Science, v.94, p.156161, 2015. DOI: 10.3382/ps/peu039.

NASCIMENTO, G.R.; NÄÄS, I.A.; PEREIRA, D.F.; BARACHO, M.S.; GARCIA, R. Assessment of broilers surface temperature variation when exposed to different air temperature. Revista Brasileira de Ciência Avícola, v.13, p.259-263, 2011. DOI: 10.1590/S1516-635X2011000400007.

PEREIRA, D.F.; BATISTA, E. dos S.; SANCHES, F.T.; GABRIEL FILHO, L.R.A.; BUENO, L.G. de F. Diferenças comportamentais de poedeiras em diferentes ambientes térmicos. Energia na Agricultura, v.30, p.33-40, 2015. DOI: 10.17224/ EnergAgric.2015v30n1p33-40.

RENAUDEAU, D.; COLLIN, A.; YAHAV, S.; BASILIO, V. de; GOURDINE, J.L.; COLLIER, R.J. Adaptation to hot climate and strategies to alleviate heat stress in livestock production. Animal, v.6, p.707-728, 2012. DOI: 10.1017/S1751731111002448.

RIBEIRO, T.L.A.; SOUZA, B.B. de; BRANDÃO, P.A.; ROBERTO, J.V.B.; MEDEIROS, T.T.B.; SILVA, J.J. da; CARVALHO JÚNIOR, J.E.M. de. Diferentes níveis de proteína e energia sobre o comportamento fisiológico e desempenho de codornas europeias no semiárido brasileiro. Journal of Animal Behaviour and Biometeorology, v.4, p.76-83, 2016. DOI: 10.14269/2318-1265/jabb.v4n3p76-83.

RODRIGUES, V.C.; BARBOSA FILHO, J.A.D.; SILVA, I.J.O. Visão computacional: distribuição espacial de aves poedeiras em condições de conforto e estresse. Engenharia Rural, v.18, p.9-16, 2007. 
RUZAL, M.; SHINDER, D.; MALKA, I.; YAHAV, S. Ventilation plays an important role in hens' egg production at high ambient temperature. Poultry Science, v.90, p.856-862, 2011. DOI: 10.3382/ps.2010-00993.

SANTOS, M.J.B. dos; RABELLO, C.B.-V.; PANDORFI, H.; TORRES, T.R.; SANTOS, P.A. dos; CAMELO, L.C.L. Fatores que interferem no estresse térmico em frangos de corte. Revista Eletrônica Nutritime, v.9, p.1779-1786, 2012.

SCHIASSI, L.; YANAGI JUNIOR, T.; FERRAZ, P.F.P.; CAMPOS, A.T., SILVA, G.R. e.; ABREU, L.H.P. Comportamento de frangos de corte submetidos a diferentes ambientes térmicos. Engenharia Agrícola, v.35, p.390-396, 2015. DOI: 10.1590/18094430-Eng.Agric.v35n3p390-396/2015.

SOUSA, M.S.; TINÔCO, I. de F.F.; BARRETO, S.L. de T.; AMARAL, A.G. do; PIRES, L.C.; FERREIRA, A.S.
Determinação de limites superiores da zona de conforto térmico para codornas de corte aclimatizadas no Brasil de 22 a 35 dias de idade. Revista Brasileira de Saúde e Produção Animal, v.15, p.350-360, 2014. DOI: 10.1590/S1519-99402014000200019.

SOUSA, M.S.; TINÔCO, I. de F.F.; MENDES, L.B.; REIS, R. de S.; FIGUEIREDO, E.M. de; QUEIROZ, P. Qualidade do ambiente aéreo na criação de codornas de corte mantidas em diferentes temperaturas. Tecnologia e Ciência Agropecuária, v.7, p.1-6, 2013.

VERCESE, F.; GARCIA, E.A.; SARTORI, J.R.; SILVA, A. de P.; FAITARONE, A.B.G.; BERTO, D.A.; MOLINO, A. de B.; PELÍCIA, K. Performance and egg quality of Japanese quails submitted to cyclic heat stress. Revista Brasileira de Ciência Avícola, v.14, p.37-41, 2012. DOI: 10.1590/S1516635X2012000100007.

Received on July 7, 2016 and accepted on November 11, 2016 